\title{
Juglone potentiates TRAIL-induced apoptosis in human melanoma cells via activating the ROS-p38-p53 pathway
}

\author{
XIAO LIU ${ }^{1 *}$, YAN CHEN $^{2 *}$, YAOHUA ZHANG ${ }^{1}$, JUAN DU $^{1}$, YUBAO LV $^{3}$, \\ SHUMING MO ${ }^{4}$, YINGCHAO LIU ${ }^{5}$, FENG DING ${ }^{5}$, JINFENG WU ${ }^{1}$ and $\mathrm{JI} \mathrm{LI}^{3}$ \\ ${ }^{1}$ Department of Dermatology, Huashan Hospital, Fudan University, Shanghai 200040; ${ }^{2}$ Department of Dermatology, \\ The Affiliated Hospital, North Sichuan Medical College, Nanchong, Sichuan 637000; ${ }^{3}$ Department of Integrative Medicine, \\ Huashan Hospital, Fudan University, Shanghai 200040; ${ }^{4}$ Department of Integrative Medicine, North Huashan Hospital, \\ Fudan University, Shanghai 201907; ${ }^{5}$ Department of Neurosurgery, Provincial Hospital Affiliated \\ to Shandong University, Jinan 250021, P.R. China
}

Received September 28, 2016; Accepted August 8, 2017

DOI: $10.3892 / \mathrm{mmr} .2017 .7806$

\begin{abstract}
Tumor necrosis factor-related apoptosis-inducing ligand (TRAIL)-based cancer therapy offers promise as TRAIL can kill cancer cells without apparent toxicity towards normal cells. However, intrinsic or acquired resistance to TRAIL inseveral types of cancer cell has become a major challenge in TRAIL-based cancer therapy. Juglone is a natural compound isolated from walnut trees. In the present study, it was demonstrated that juglone sensitized melanoma cells to TRAIL-induced cytotoxicity by MTT and crystal violet assays. Flow cytometry analysis indicated that juglone potentiated TRAIL-induced cell death. Western blot assay demonstrated that the expressions of cleaved poly(ADP-ribose) polymerase (PARP) and cleaved caspase 3 were markedly increased in the juglone combined with TRAIL group. Exposure to TRAIL alone did not induce the production of reactive oxygen species (ROS), activation of p38 orincrease of p53 in the TRAIL-resistant melanoma cells, as determined by flow cytometry and western blot analysis. However, exposure to TRAIL in combination with juglone markedly increased the production of ROS, activated p38 and increased p53, compared with the cells treated with either juglone or TRAIL alone. Pretreatment with $\mathrm{N}$-acetyl cysteine, a ROS scavenger, significantly reduced the cytotoxicity of juglone in
\end{abstract}

Correspondence to: Dr Ji Li, Department of Integrative Medicine, Huashan Hospital, Fudan University, 12 Middle Urumqi Road, Shanghai 200040, P.R. China

E-mail: thomas19991015@163.com

Dr Jinfeng Wu, Department of Dermatology, Huashan Hospital, Fudan University, 12 Middle Urumqi Road, Shanghai 200040, P.R. China

E-mail:wujinfeng21@163.com

*Contributed equally

Key words: juglone, tumor necrosis factor-related apoptosis-inducing ligand, melanoma, reactive oxygen species, p38, p53 combination with TRAIL, which further supported that ROS was involved in the juglone-induced sensitization of TRAIL. In conclusion, juglone potentiated TRAIL-induced apoptosis in melanoma cells, and these effects were partially mediated through the ROS-p38-p53 pathway. These findings suggested that juglone may be a potential sensitizer for TRAIL therapy in the treatment of melanoma.

\section{Introduction}

The incidence of melanoma in men and women has continued to increase in the last 40 years, despite stable or decreasing trends for the majority of types ofcancer (1). The use of targeted drugs, including vemurafenib, dabrafenib and trametinib, and immunotherapeutic drugs, including ipilimumab, pembrolizumab and nivolumab, for melanoma treatment were approved by the US Food and Drug Administration in the last 5 years (2). All of these drugs have been shown to result in a significant increase in progression-free and overall survival rates, with long-term benefits in multiple clinical trials (2). However, these therapies have several limitations and challenges, including drug resistance, immune-related adverse events and a lack of predictive biomarkers (2). Therefore, the development of novel agents is required to overcome the limitations of currently used therapeutic agents.

Tumor necrosis factor-related apoptosis-inducing ligand (TRAIL) is a member of tumor necrosis factor (TNF) superfamily. TRAIL can induce the apoptosis of cells in several types of cancer without causing obvious toxicity to normal cells (3-5). Currently, recombinant human TRAIL is being assessed in clinical trials (6). However, limited therapeutic benefit has been observed and almost $50 \%$ of cancer cells, including melanoma cells, have shown resistance to TRAIL (7). TRAIL resistance has become a major challenge in TRAIL-based cancer therapy. Reactive oxygen species (ROS) are known to induce a wide range of responses, which are dependent on cell type and the levels of ROS within the cells $(8,9)$. High levels of ROS can lead to necrotic cell death, whereas low levels of ROS have been shown to induce apoptotic cell death $(8,9)$. It has been reported that TRAIL 
exposure can induce the accumulation of ROS, activation of p38 mitogen-activated protein kinase (MAPK), enhancement of the expression of p53 and activation of caspases with subsequent apoptosis in TRAIL-sensitive cancer cells $(10,11)$. In TRAIL-resistant cancer cells, natural ROS inducers, including curcumin (12), sulforaphane (13), baicalein (14) and icariside II (15), have been reported to overcome TRAIL resistance in cancer cells.

Juglone (5-hydroxy-1,4-naphthoquinone), is a natural compound isolated from the roots, leaves, woods and fruits of walnut trees. It exhibits various pharmacological effects, including antiviral, antibacterial and antifungal effects $(16,17)$. Previous studies have shown that juglone is cytotoxic towards cells in several types of cancer, including human lung cancer (A549) cells (18), human leukemia (HL-60) cells (19) and human cervical carcinoma (HeLa) cells (20). It has been documented that juglone exerts its cytotoxic effect via the production of ROS (21-23). In the present study, the effect of juglone on TRAIL-induced cytotoxicity was examined. It was shown that juglone potentiated TRAIL-induced apoptosis in melanoma cells, and that these effects were partially mediated through the ROS-p38-p53 pathway.

\section{Materials and methods}

Reagents and cell culture. Juglone was purchased from Sigma-Aldrich; Merck Millipore (Darmstadt Germany; purity>97; CAS 481-39-0; Fig. 1A) and dissolved in dimethyl sulfoxide (DMSO). The final concentration of DMSO used was $<0.1 \%(\mathrm{v} / \mathrm{v})$. The human melanoma A2058 and MEWO cells were obtained from American Type Culture Collection (Manassas, VA, USA) and maintained in DMEM (Invitrogen; Thermo Fisher Scientific, Inc., Waltham, MA, USA) containing $4 \mathrm{mM}$ L-glutamine, $3.7 \mathrm{~g} / 1$ sodium bicarbonate, $4.5 \mathrm{~g} / 1$ glucose and $10 \%$ fetal bovine serum (FBS; Invitrogen;Thermo Fisher Scientific, Inc.). The cells were maintained in a $5 \% \mathrm{CO}_{2}$ humidified incubator at $37^{\circ} \mathrm{C}$. Human recombinant TRAIL was purchased from PeproTech, Inc. (Rocky Hill, NJ, USA). Propidiumiodide (PI) and RNaseA were supplied by Beyotime Institute of Biotechnology (Jiangsu, China). The antibodies targeting phosphorylated (p)-p38 (cat. no. 4511), p38 (cat. no. 8690), p53 (cat. no. 2527), poly(ADP-ribose) polymerase (PARP, cat. no. 9542), caspase 3 (cat. no. 9662), and GAPDH (cat. no. 5174) were obtained from Cell Signaling Technology, Inc. (Beverly, MA, USA). Thiazolylblue tetrazolium bromide (MTT), and N-acetyl-L-cysteine (NAC) were supplied by Sigma-Aldrich; Merck Millipore.

Cell viability assays. The cytotoxic effects of juglone and/or TRAIL on the A2058 and MEWO cells were determined using an MTT assay. Cells $(4,000 / 200 \mu \mathrm{l} /$ well) were seeded into 96-well plates and pretreated with juglone $(0,10$ or $20 \mu \mathrm{M})$ for 6 hat $37^{\circ} \mathrm{C}$. The cells were then washed with PBS, and the medium was replaced, following which the cells were treated with TRAIL (0 and $25 \mathrm{ng} / \mathrm{ml})$ for $24 \mathrm{~h}$ at $37^{\circ} \mathrm{C}$. Subsequently, $20 \mu \mathrm{l}$ of MTT solution $(5 \mathrm{mg} / \mathrm{ml})$ was added to each well and incubated for $2 \mathrm{~h}$ at $37^{\circ} \mathrm{C}$. The formazan crystals formed were dissolved with $100 \mu \mathrm{l}$ of DMSO and the optical density (OD) was detected at $570 \mathrm{~nm}$ onamicroplate spectrophotometer (BD Biosciences, SanJose, CA, USA). The cell viability was determined using the following formula: Ratio $(\%)=($ ODtreatment/ODvehicle control $) \times 100$. For the crystal violetassay, the cells $\left(2.5 \times 10^{5}\right)$ were seeded into $60 \mathrm{~mm}$ dishes and exposed to juglone ( 0 and $20 \mu \mathrm{M})$ for $6 \mathrm{~h}$. The cells were then washed with PBS and the medium was replaced, following which the cells were treated withTRAIL $(0$ and $25 \mathrm{ng} / \mathrm{ml})$ for $72 \mathrm{~h}$. The cells were then fixed with $10 \%$ formalin for 10 min, followed by staining with $0.05 \%$ crystal violet solution in distilled water for $30 \mathrm{~min}$. Finally, the crystal violet was removed, and the cells were washed twice with distilled water. Cells were visualized using a light microscope and images of them were captured by a Flatbed Scanner (Canon LiDE 220, Canon Inc., Tokyo, Japan).

Cell death assays. The A2058 and MEWO cells were seeded at a density of $2 \times 10^{5}$ cells/well in 6 -well culture plates for $24 \mathrm{~h}$. Subsequently, the cells were pretreated with juglone ( 0 and $20 \mu \mathrm{M}$ ) for $6 \mathrm{~h}$. The cells were then washed with PBS and medium was replaced, following which the cells were treated with TRAIL ( 0 and $25 \mathrm{ng} / \mathrm{ml}$ ) for $24 \mathrm{~h}$. Following incubation, the cells were collected and fixed in $70 \%$ ethanol for $24 \mathrm{~h}$ at $4^{\circ} \mathrm{C}$. The cells were then centrifuged at $300 \mathrm{x} \mathrm{g}$ at $4^{\circ} \mathrm{C}$ for $10 \mathrm{~min}$ and the cell pellet was resuspended in $400 \mu \mathrm{l}$ of PBS containing RNaseA $(10 \mathrm{mg} / \mathrm{ml} ; 50 \mu \mathrm{l})$ and PI $(2 \mathrm{mg} / \mathrm{ml} ; 10 \mu \mathrm{l})$. The mixture was incubated in the dark at $37^{\circ} \mathrm{C}$ for $30 \mathrm{~min}$ and analyzed using a FACSCalibur flow cytometer (BD Biosciences). The cell death data were analyzed using FlowJo software V6.0 (Tree Star, Inc., Ashland, OR, USA). The extent of cell death was determined by evaluating the sub G1 fraction. The data comprised three replicates.

Western blot analysis. The A2058 cells were pretreated with juglone $(0$ and $20 \mu \mathrm{M})$ for $6 \mathrm{~h}$. The cells were then washed with PBS and medium was replaced, following which the cells were treated with TRAIL ( 0 and $25 \mathrm{ng} / \mathrm{ml}$ ) for $4 \mathrm{~h}$. The cells were then resuspended in lysis buffer containing $150 \mathrm{mmol} / \mathrm{l}$ NaCL, $1 \%$ NP-40, $0.5 \%$ sodium deoxycholate, $0.1 \%$ SDS, and $50 \mathrm{mmol} / \mathrm{l}$ Tris- $\mathrm{Cl}(\mathrm{pH} 8.0), 2 \mu \mathrm{g} / \mathrm{ml}$ aprotinin, $2 \mu \mathrm{g} / \mathrm{ml}$ leupeptin, $40 \mathrm{mg} / \mathrm{ml}$ of phenylmethylsulfonyl fluoride and $2 \mathrm{mmol} / \mathrm{l}$ DTT. The mixture was centrifuged at $10,000 \mathrm{x} \mathrm{g}$ at $4^{\circ} \mathrm{C}$ for $15 \mathrm{~min}$ to remove nuclei and cell debris. The supernatants were then immediately frozen at $-80^{\circ} \mathrm{C}$ until use. The protein concentrations were determined using a Bradford assay (Bio-Rad Laboratories, Inc., Hercules, CA, USA) and $30 \mu \mathrm{g}$ of cellular proteins were electroblotted onto a PVDF membrane following separation via $10 \%$ SDS-polyacrylamide gel electrophoresis. The immunoblot was blocked for $1 \mathrm{~h}$ with $5 \%$ milk at room temperature, followed by incubation overnight at $4^{\circ} \mathrm{C}$ with 1:1,000 dilutions of primary antibodies against p-p38, p38, p53, PARP, caspase 3 or GAPDH. The blots were washed twice with Tween 20/Tris-buffered saline (TTBS) prior to the addition of a 1:1,000 dilution of HRP-conjugated secondary antibody (cat. no. 7074, Cell Signaling Technology Inc., Danvers, MA, USA) for $1 \mathrm{~h}$ at room temperature. The blots were washed again with TTBS, and developed by enhanced chemiluminescence using Supersignal West Femto Chemiluminescent substrate (Pierce; Thermo Fisher Scientific, Inc.). The band intensities were quantified using UN-SCAN-IT gel analysis software (version 6; Silk Scientific, Orem, UT, USA). The OD values for the target proteins were calculated 
A<smiles>O=C1C=CC(=O)C2C(=O)C=CC=C12</smiles>

B

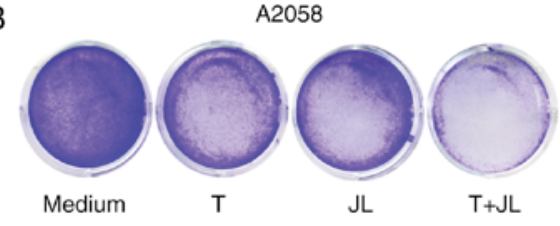

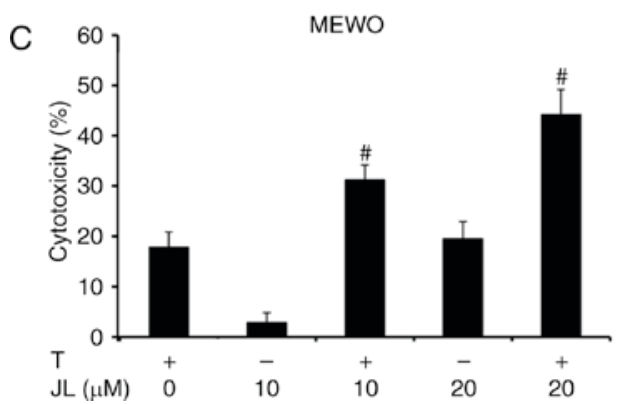

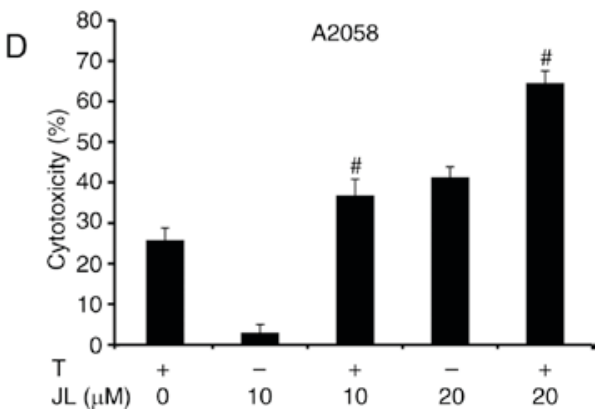

Figure 1. Juglone sensitizes melanoma cells to TRAIL-induced cytotoxicity. (A) Chemical structure of juglone. (B) Crystal violet assay. A2058 cells were exposed to juglone ( 0 and $20 \mu \mathrm{M})$ for $6 \mathrm{~h}$, following which cells were washed with PBS and treated with TRAIL (0 and $25 \mathrm{ng} / \mathrm{ml})$ for $72 \mathrm{~h}$. The cells were fixed and stained with crystal violet solution. (C) Cytotoxicity assay of MEWO cells and (D) A2058 cells. MEWO and A2058 cells were pretreated with juglone $(0,10$ and $20 \mu \mathrm{M})$ for $6 \mathrm{~h}$, washed with PBS and medium was replaced, following which cells were treated with TRAIL ( 0 and $25 \mathrm{ng} / \mathrm{ml})$ for $24 \mathrm{~h}$. Thiazolylblue tetrazolium bromide solution was added and the absorbance was detected at $570 \mathrm{~nm}$. ${ }^{\text {P }}<0.01$, vs. JL or Talone. JL, juglone; T/TRAIL, tumor necrosis factor-related apoptosis-inducing ligand.

as a proportion of the OD value for GAPDH. The western blot assays were repeated three times.

Evaluation of ROS. ROS were detected using the cell-permeable fluorescentprobe 2,-7,-dichlorofluorescein-diacetate ( $\mathrm{H}_{2} \mathrm{DCFDA}$; Sigma-Aldrich; Merck Millipore), a non-fluorescent compound, which is converted into highly fluorescent dichlorofluorescein (DCF) by cellular peroxides. Briefly, the A2058 cells were pretreated with juglone (0 and $20 \mu \mathrm{M})$ for $6 \mathrm{~h}$. The cells then were washed with PBS and medium was replaced, following which the cells were treated with TRAIL ( 0 and $25 \mathrm{ng} / \mathrm{ml}$ ) for $4 \mathrm{~h}$. Following treatment, the cells were loaded with $\mathrm{H}_{2}$ DCFDA $(10 \mu \mathrm{M})$ in serum-free DMEM. Following incubation at $37^{\circ} \mathrm{C}$ for $30 \mathrm{~min}$, the cells were washed with PBS and fluorescence was monitored using flow cytometry at an excitation wave length of $488 \mathrm{~nm}$ and emission wavelength of $530 \mathrm{~nm}$. The mean fluorescence intensity (MFI) data were analyzed using FlowJo software V6.0 (Tree Star, Inc.) and included three replicates.

Statistical analysis. All data are presented as the mean \pm standard deviation. Statistical analysis was performed by SPSS Statistics 17.0 software (SPSS Inc., Chicago, IL, USA) using one-way analysis of variance. For comparisons between two groups, Student's t-test was used. $\mathrm{P}<0.05$ was considered to indicate a statistically significant difference.

\section{Results}

Juglone sensitizes melanoma cells to TRAIL-induced cytotoxicity. The present study first examined the cytotoxic effects of juglone and/or TRAIL in TRAIL-resistant melanoma cells. As demonstrated bythe crystal violet assay (Fig. 1B) and MTT assay (Fig. 1C and D), the MEWO and A2058 melanoma cells exhibited a low level response to
TRAIL treatment. Juglone (10 and $20 \mu \mathrm{M})$ treatment alone induced cytotoxicity in a dose-dependent manner, whereas a higher level of cytotoxicity was observed in the juglone and TRAIL combination group, compared with that inthe groups treated with either TRAIL or juglone alone $(\mathrm{P}<0.01)$.

Juglone potentiates TRAIL-induced cell death. As demonstrated by the flow cytometric analysis (Fig. 2), MEWO melanoma cells were not affected by TRAIL-induced cell death (Fig. 2A and C), whereas the A2058 cells exhibited a minor response to TRAIL-induced cell death (Fig. 2B and C). Treatment with juglone $(20 \mu \mathrm{M})$ alone significantly induced cell death, however, the combination of juglone and TRAIL caused a higher rate of cell death, compared with that in the cells treated with either TRAIL or juglone alone (Fig. 2; $\mathrm{P}<0.01)$.

PARP and caspase 3 are the terminal pro-apoptotic proteins. The cleaved forms of these two proteins are the active forms. As demonstrated in the results of the western blot analysis (Fig. 3), no significant changes in the expression of PARP and caspase 3 were observed in the group treated with TRAIL alone. However, juglone treatment markedly increased the expression of cleaved PARP (Fig. 3A and B) and cleaved caspase 3 (Fig. 3A and C). The levels of cleaved PARP and cleaved caspase 3 in the juglone and TRAIL combination group were higher, compared with the levels in the group treated with juglone alone (Fig. 3; $\mathrm{P}<0.01)$. Significant decreases in the levels of pro-PARP and pro-caspase 3 were observed following combined juglone and TRAIL treatment.

Juglone and TRAIL combination treatment increases the production of ROS, and activates p38 and p53. To examine the molecular mechanism underlying juglone-induced TRAIL sensitization, the present study investigated whether juglone 

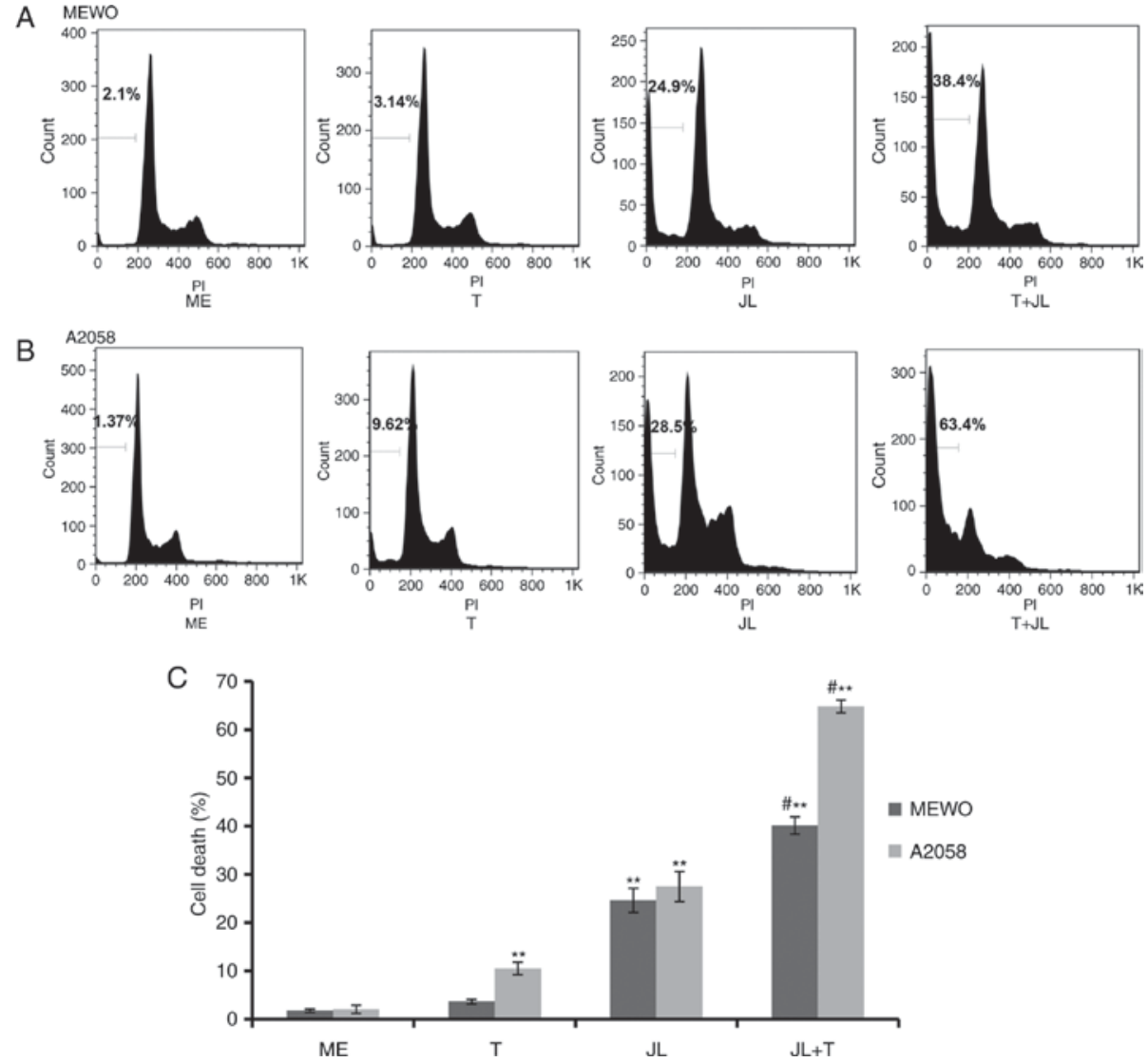

Figure 2. Juglone potentiates TRAIL-induced melanoma cell death. Representative results of (A) MEWO cell death and (B) A2058 cell death. (C) Statistical analysis of cell death data. MEWO and A2058 cell were exposed to juglone $(0$ and $20 \mu \mathrm{M})$ for $6 \mathrm{~h}$, washed with PBS and treated with TRAIL ( 0 and $25 \mathrm{ng} / \mathrm{ml})$ for $24 \mathrm{~h}$. Following fixation, the cells were stained with PI and analyzedin a FACSCalibur cytometer. The cell death experiments were repeated three times. ${ }^{* *} \mathrm{P}<0.01$, vs. control; ${ }^{*} \mathrm{P}<0.01$, vs. JLor Talone. ME, medium; JL, juglone; T/TRAIL, tumor necrosis factor-related apoptosis-inducing ligand; PI, propidium iodide.
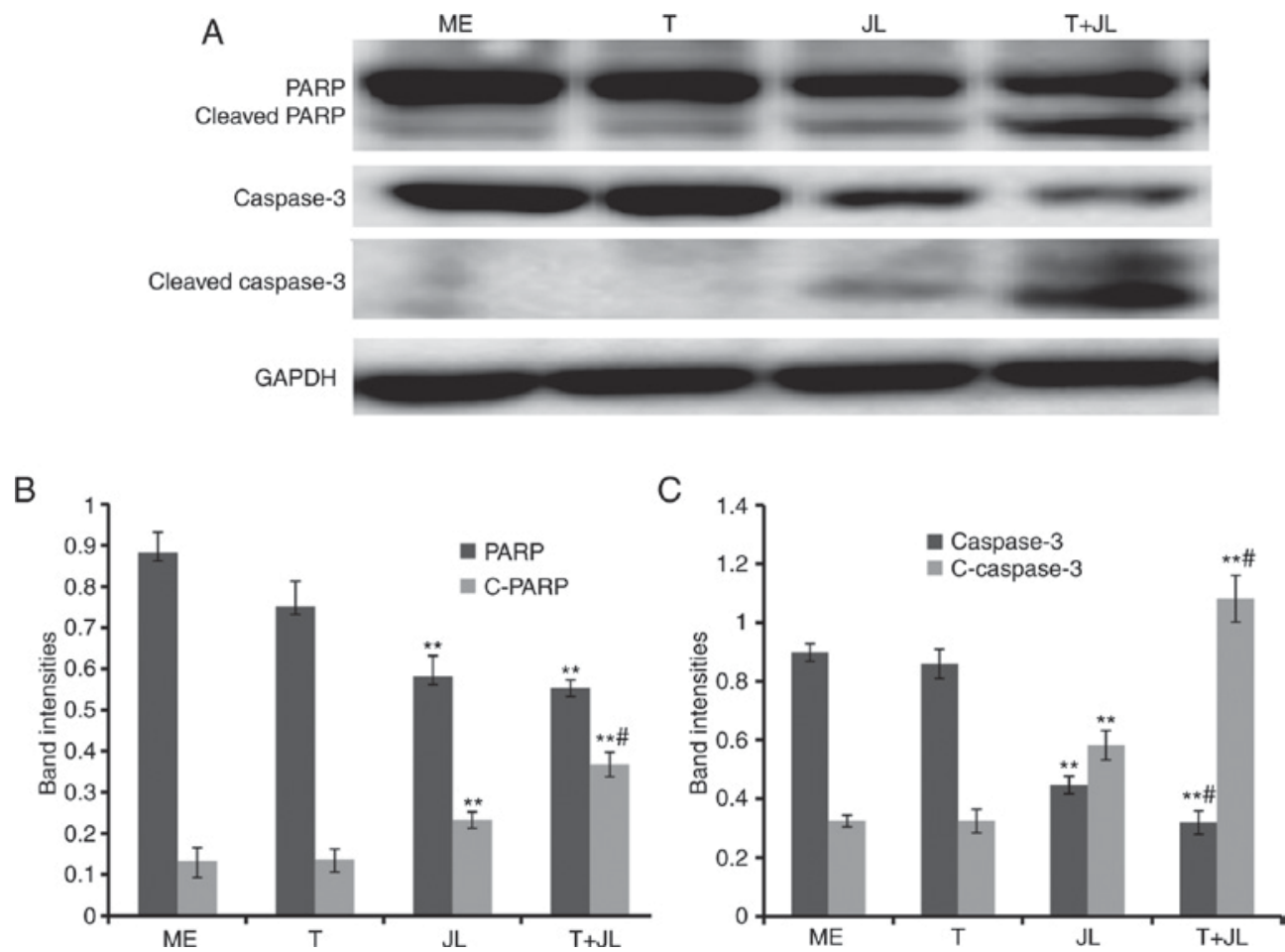

Figure 3. Juglone in combination with TRAIL increases levels of cleaved caspase 3 and cleaved PARP. (A) Representative western blot images of PARP and caspase 3. (B) Quantification of band intensities of PARP and (C) caspase 3. A2058 cells were pretreated with juglone $(0$ and $20 \mu \mathrm{M})$ for $6 \mathrm{~h}$, washed with PBS andtreated with TRAIL ( 0 and $25 \mathrm{ng} / \mathrm{ml}$ ) for $4 \mathrm{~h}$. Caspase 3 and PARP were detected using western blot analysis. The band densities for target proteins are shown as a proportion of that for GAPDH. ${ }^{* *} \mathrm{P}<0.01$, vs. ME control; ${ }^{*} \mathrm{P}<0.01$, vs. JL or TRAIL alone. ME, medium; JL, juglone; T/TRAIL, tumor necrosis factor-related apoptosis-inducing ligand; PARP, poly(ADP-ribose) polymerase; $\mathrm{C}-$-, cleaved. 
A

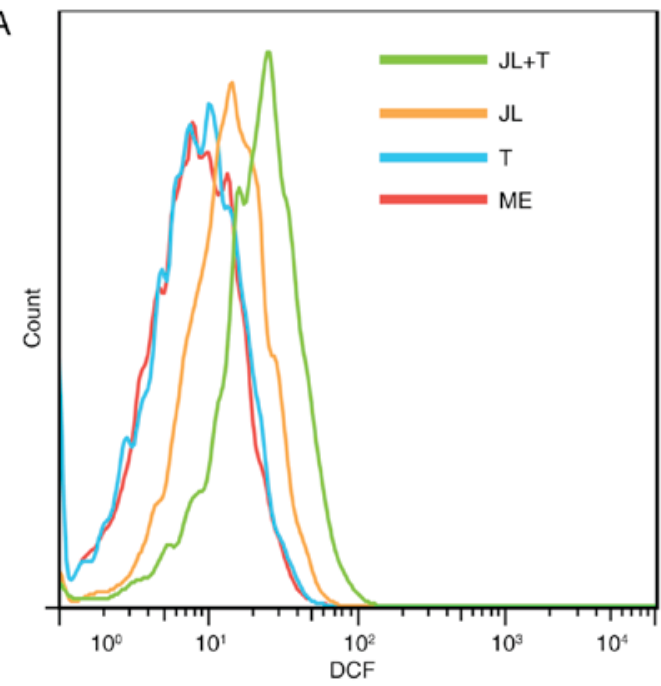

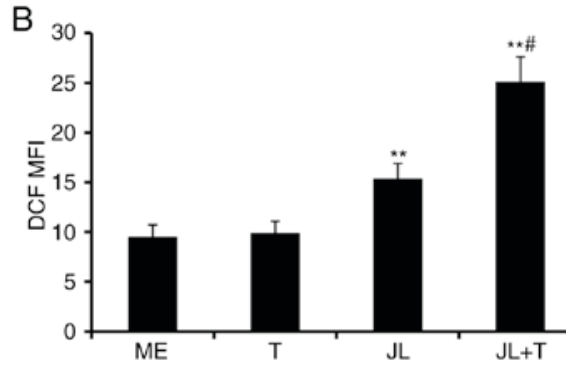

C

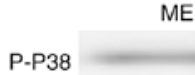

T

JL

JL+T
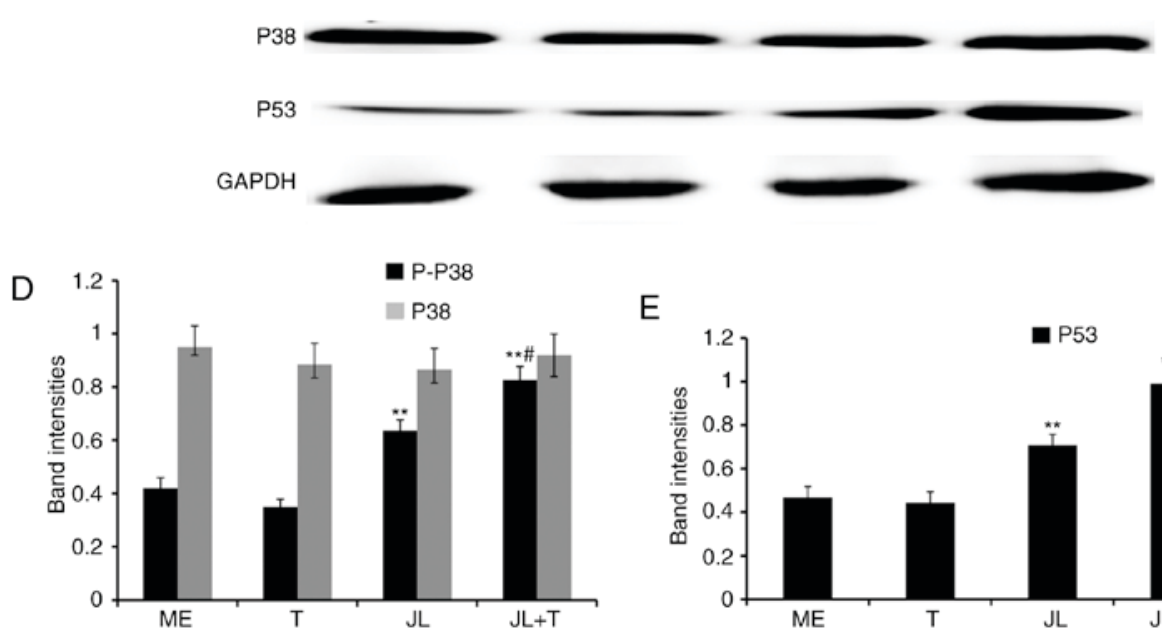

E

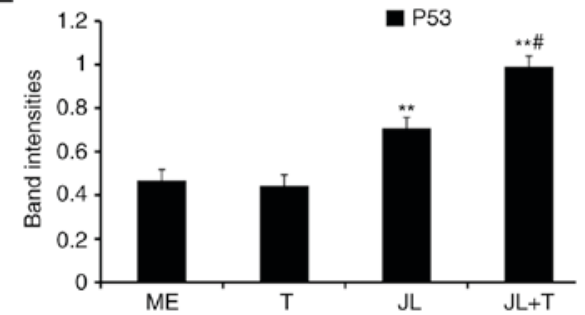

F
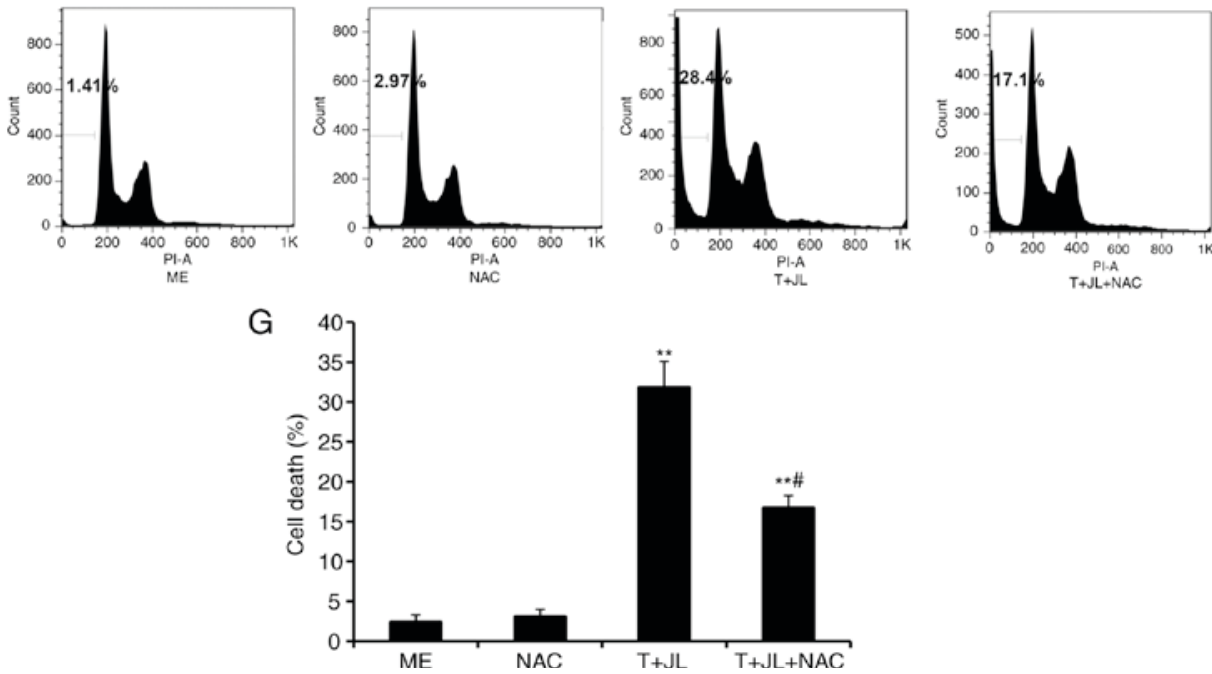

Figure 4. Juglone in combination with TRAIL increases the production of ROS, and activates p38 and p53. For the ROS assay, A2058 cells were pretreated with juglone $(0$ and $20 \mu \mathrm{M})$ for $6 \mathrm{~h}$, washed with PBS, and treated with TRAIL ( 0 and $25 \mathrm{ng} / \mathrm{ml})$ for $4 \mathrm{~h}$. The cells were loaded with $\mathrm{H}_{2}$ DCFDA and fluorescence was monitored by flow cytometry. MFI data were analyzed using FlowJo software V6.0. (A) Representative images of ROS MFI and (B) statistical data. For western blot analysis, the cells were treated with juglone and/or TRAIL for $4 \mathrm{~h}$, total protein was extracted, and p-p38, p38 and p53 were detected. GAPDH was used as the loading control. (C) Representative western blot images of p-p38, total p38 and p53, and quantification of band intensities of (D) p-p38, total p38 and (E) p53. The band densities for target protein are shown as a proportion of that for GAPDH. For the cell death assay, A2058 cells were pretreated with NAC $(0$ and $2 \mathrm{mM})$ for $1 \mathrm{~h}$, followed by juglone and TRAIL combination treatment for $16 \mathrm{~h}$. The fixed cells were stained with PI and analyzed in a FACSCalibur cytometer, with experiments repeated three times. (F) Representative images of cell death and (G) statistical analysis. ${ }^{* *} \mathrm{P}<0.01$, vs. ME control; ${ }^{*} \mathrm{P}<0.01$, vs. JLor T alone. ME, medium; JL, juglone; T/TRAIL, tumor necrosis factor-related apoptosis-inducing ligand; P-, phosphorylated; ROS, reactive oxygen species; DCF MFI, dichlorofluorescein mean fluorescence intensity; PI, propidium iodide. 
and/or TRAIL treatment induced the production of ROS. The ROS levels were determined $6 \mathrm{~h}$ following juglone and/or TRAIL treatment. As demonstrated by the flow cytometric analysis (Fig. 4A and B), TRAIL treatment alone did not increase the production of ROS, whereas juglone treatment alone significantly increased the production of ROS $(\mathrm{P}<0.01)$ The production of ROS was further increased in the juglone and TRAIL combination group, compared with the cells treated with juglone alone $(\mathrm{P}<0.01)$.

Previous evidence indicates that ROS induces cell death via the activation of p38 and p53 $(10,11)$. As demonstrated by western blot analysis (Fig. 4C-E), treatment with TRAIL alone did notactivated p38 and p53, whereas treatment with juglone alone significantly increased the levels of p-p38 and p53 $(\mathrm{P}<0.01)$. The expression levels of $\mathrm{p}-\mathrm{p} 38$ and $\mathrm{p} 53$ were further increased in the juglone and TRAIL combination group, as compared with the group treated with juglone alone $(\mathrm{P}<0.01)$. No significant change was observed in the protein expression of total p38 following juglone and/or TRAIL treatment.

NAC pretreatment partially reverses juglone and TRAIL combination-induced cell death. As demonstrated by the flow cytometric analysis (Fig. 4F and G), treatment with juglone in combination with TRAIL for $16 \mathrm{~h}$ resulted in a significant increase in the rate of cell death (28.4\%), compared with that in the medium control group (1.41\%), whereas pretreatment with NAC, a ROS scavenger, partially reversed the juglone and TRAIL combination-induced cell death $(\mathrm{P}<0.01 ; 14.7$, vs. $28.4 \%)$.

\section{Discussion}

Intrinsic or acquired resistance to TRAIL in several types of cancer cell has become a major challenge in TRAIL-based cancer therapy. In the present study, it was found that juglone sensitized melanoma cells to TRAIL-induced cytotoxicity, which was accompanied by increases in the levels of cleaved PARP and cleaved caspase 3 .

It has been reported that TRAIL exposure can induce the accumulation of ROS and activation of p38 MAPK, enhance the expression of $\mathrm{p} 53$ and activate caspases in TRAIL-sensitive cancer cells. In the present study, it was found that TRAIL exposure did not induce the production of ROS, activation of p38 or increase in p53 in the TRAIL-resistant melanoma cells. However juglone in combination with TRAIL markedly increased the production of ROS and activation of $\mathrm{p} 38$, and increased the expression of $\mathrm{p} 53$, compared with the groups treated with either juglone or TRAIL alone. Pretreatment with NAC, a ROS scavenger, significantly reduced the cytotoxicity of juglone in combination with TRAIL, which further supported the hypothesis that ROS is involved in juglone-induced TRAIL sensitization.

The resistance of several types of cancer cell to TRAIL is partially due to decreased levels or mutations of TRAIL receptors, including death receptor 4 (DR4) and DR5 $(24,25)$. The sensitivity of cancer cells to TRAIL can be partially restored by treatment with subtoxic concentrations of chemotherapeutic drugs through the upregulation of DR4 and DR5 $(26,27)$. Several studies have shown that DR4 and DR5 can be upregulated by ROS and MAPKs, including extracellular signal-regulated kinases1/2, p38 MAPK and c-Jun $\mathrm{NH}_{2}$-terminal kinase (28-30). As juglone could increase the production of ROS and increase p-p38 and p53 protein levels, further investigations are required to determine the effects of juglone on DR4 and DR5 TRAIL receptors.

In conclusion, the present study demonstrated that juglone, a natural product from walnut trees, potentiated TRAIL-induced apoptosis in melanoma cells and that these effects were partially mediated through the ROS-p38-p53 pathway. These findings suggest that juglone maybe a potential sensitizer for TRAIL in the treatment of melanoma.

\section{Acknowledgements}

This study was funded by grants from the National Natural Science Foundation of China (grant no. 81673917) and the Shandong Provincial Natural Science Foundation (grant no. ZR2014HM069, ZR2014HM002).

\section{References}

1. Siegel RL, Miller KD and Jemal A: Cancer statistics, 2015. CA Cancer J Clin 65: 5-29, 2015.

2. Zhu Z, Liu W and Gotlieb V: The rapidly evolving therapies for advanced melanoma-Towards immunotherapy, molecular targeted therapy, and beyond. Crit Rev Oncol Hematol 99: 91-99, 2016.

3. Takeda K, Stagg J, Yagita H, Okumura K and Smyth MJ: Targeting death-inducing receptors in cancer therapy. Oncogene 26: 3745-3757, 2007

4. Wang S: The promise of cancer therapeutics targeting the TNF-related apoptosis-inducing ligand and TRAIL receptor pathway. Oncogene 27: 6207-6215, 2008.

5. Falschlehner C, Ganten TM, Koschny R, Schaefer U and Walczak H: TRAIL and other TRAIL receptor agonists as novel cancer therapeutics. Adv Exp Med Biol 647: 195-206, 2009.

6. Bellail AC, Qi L, Mulligan P, Chhabra V and Hao C: TRAIL agonists on clinical trials for cancer therapy: The promises and the challenges. Rev Recent Clin Trials 4: 34-41, 2009.

7. Zhang L and Fang B:Mechanisms of resistance to TRAIL-induced apoptosis in cancer. Cancer Gene Ther 12: 228-237, 2005.

8. Kannan K, Holcombe RF, Jain SK, Alvarez-Hernandez X, Chervenak R, Wolf RE and Glass J: Evidence for the induction of apoptosis by endosulfan in a human T-cell leukemic line. Mol Cell Biochem 205: 53-66, 2000.

9. Kannan K and Jain SK: Oxidative stress and apoptosis. Pathophysiology 7: 153-163, 2000.

10. Lee MW, Park SC, Yang YG, Yim SO, Chae HS, Bach JH, Lee HJ, Kim KY, Lee WB and Kim SS: The involvement of reactive oxygen species (ROS) and p38 mitogen-activated protein (MAP) kinase in TRAIL/Apo2L-induced apoptosis. FEBS Lett 512: 313-318, 2002.

11. Lamy V, Bousserouel S, Gossé F, Minker C, Lobstein A and Raul F: Lupulone triggers p38 MAPK-controlled activation of p53 and of the TRAIL receptor apoptotic pathway in human colon cancer-derived metastatic cells. Oncol Rep 26: 109-114, 2011.

12. Park S, Cho DH, Andera L, Suh N and Kim I: Curcumin enhances TRAIL-induced apoptosis of breast cancer cells by regulating apoptosis-related proteins. Mol Cell Biochem 383: 39-48, 2013.

13. Kim H, Kim EH, Eom YW, Kim WH, Kwon TK, Lee SJ and Choi KS: Sulforaphane sensitizes tumor necrosis factor-related apoptosis-inducing ligand (TRAIL)-resistant hepatoma cells to TRAIL-induced apoptosis through reactive oxygen species-mediated up-regulation of DR5. Cancer Res 66: 1740-1750, 2006.

14. Taniguchi H, Yoshida T, Horinaka M, Yasuda T, Goda AE, Konishi M, Wakada M, Kataoka K, Yoshikawa T and Sakai T: Baicalein overcomes tumor necrosis factor-related apoptosis-inducing ligand resistance via two different cell-specific pathways in cancer cells but not in normal cells. Cancer Res 68: 8918-8927, 2008.

15. Du J, Wu J, Fu X, Tse AK, Li T, Su T and Yu ZL: Icairiside II overcomes TRAIL resistance of melanoma cells through ROS-mediated downregulation of STAT3/cFLIP signaling. Oncotarget 7: 52218-52229, 2016. 
16. Omar S, Lemonnier B, Jones N, Ficker C, Smith ML, Neema C, Towers GH, Goel K and Arnason JT: Antimicrobial activity of extracts of eastern North American hardwood trees and relation to traditional medicine. J Ethnopharmacol 73: 161-170, 2000.

17. Vardhini SR: Exploring the antiviral activity of juglone by computational method. J Recept Signal Transduct Res 34: 456-457, 2014

18. Zhang XB, Zou CL, Duan YX, Wu F and Li G: Activity guided isolation and modification of juglone from Juglans regia as potent cytotoxic agent against lung cancer cell lines. BMC Complement Altern Med 15: 396, 2015.

19. Xu HL, Yu XF, Qu SC, Zhang R, Qu XR, Chen YP, Ma XY and Sui DY: Anti-proliferative effect of Juglone from Juglans mandshurica Maxim on human leukemia cell HL-60 by inducing apoptosis through the mitochondria-dependent pathway. Eur J Pharmacol 645: 14-22, 2010.

20. Zhang W, Liu A, Li Y, Zhao X, Lv S, Zhu W and Jin Y: Anticancer activity and mechanism of juglone on human cervical carcinoma HeLa cells. Can J Physiol Pharmacol 90: 1553-1558, 2012.

21. Seshadri P, Rajaram A and Rajaram R: Plumbagin and juglone induce caspase-3-dependent apoptosis involving the mitochondria through ROS generation in human peripheral blood lymphocytes. Free Radic Biol Med 51: 2090-2107, 2011.

22. Xu HL, Yu XF, Qu SC, Qu XR, Jiang YF and Sui da Y: Juglone, from Juglans mandshruica Maxim, inhibits growth and induces apoptosis in human leukemia cell HL-60 through a reactive oxygen species-dependent mechanism. Food Chem Toxicol 50: 590-596, 2012

23. Jha BK, Jung HJ, Seo I, Suh SI, Suh MH and Baek WK: Juglone induces cell death of Acanthamoeba through increased production of reactive oxygen species. Exp Parasitol 159: 100-106, 2015.
24. Kischkel FC, Lawrence DA, Chuntharapai A, Schow P, Kim KJ and Ashkenazi A: Apo2L/TRAIL-dependent recruitment of endogenous FADD and caspase- 8 to death receptors 4 and 5. Immunity 12: 611-620, 2000.

25. Daniel PT, Wieder T, Sturm I and Schulze-Osthoff K: The kiss of death: Promises and failures of death receptors and ligands in cancer therapy. Leukemia 15: 1022-1032, 2001.

26. Mühlethaler-Mottet A, Bourloud KB, Auderset K, Joseph JM and Gross N: Drug-mediated sensitization to TRAIL-induced apoptosis in caspase-8-complemented neuroblastoma cells proceeds via activation of intrinsic and extrinsic pathways and caspase-dependent cleavage of XIAP, Bcl-xL and RIP. Oncogene 23: 5415-5425, 2004.

27. Lacour S, Micheau O, Hammann A, Drouineaud V, Tschopp J, Solary E and Dimanche-Boitrel MT: Chemotherapy enhances TNF-related apoptosis-inducing ligand DISC assembly in HT29 human colon cancer cells. Oncogene 22: 1807-1816, 2003.

28. Prasad S, Kim JH, Gupta SC and Aggarwal BB: Targeting death receptors for TRAIL by agents designed by Mother Nature. Trends Pharmacol Sci 35: 520-536, 2014.

29. Bhardwaj A and Aggarwal BB: Receptor-mediated choreography of life and death. J Clin Immunol 23: 317-332, 2003.

30. Song JJ and Lee YJ: Differential cleavage of Mst1 by caspase-7/-3 is responsible for TRAIL-induced activation of the MAPK superfamily. Cell Signal 20: 892-906, 2008. 